\title{
THE EFFECT OF CLIMATE ON RADIAL GROWTH OF SCOTS PINE (Pinus sylvestris L.) IN A COASTAL MIXED STAND IN KAPISUYU, BARTIN, TURKEY
}

\author{
Halil Barış Özel, Barbaros Yaman* and Tuğrul Varol \\ Department of Forest Engineering, Faculty of Forestry, Bartin University, 74100, Bartin, Turkey
}

Received: 19 April 2021, Revised: 27 August 2021, Accepted: 19 October 2021

\begin{abstract}
THE EFFECT OF CLIMATE ON RADIAL GROWTH OF SCOTS PINE (Pinus sylvestris L.) IN A COASTAL MIXED STAND IN KAPISUYU, BARTIN, TURKEY. Scots pine is geographically the most widespread pine species in the world, and it shows different growth responses to climate and environmental factors in diverse ecological sites. We studied both the stand dynamics and climate-growth relationships of scots pine in isolated coastal stand (recently found) in the Western Black Sea Region of Turkey. The homogeneity index of this stand has varied between 1.92-3.56. In growth-ring analyses, after cross-dating of individual chronologies, COFECHA and ARSTAN software were used respectively for chronology quality control and standardization (detrend). In this way, a 58-year-long chronology (1959-2016) of scots pine was constructed. In addition, DENDROCLIM software was used for investigating scots pine's radial growth-climate relationships. Mean sensitivity changed from 0.163 to 0.331 , with a mean of 0.183 . Mean correlation among trees and signal to noise ratio were 0.389 and 7.012 respectively. In terms of the effect of precipitation on the radial growth of scots pine in this site, the correlation coefficients were $0.43(\mathrm{p}<0.05)$ for December of the previous year and $0.41(\mathrm{p}<0.05)$ for July of the current year. For all the other months, precipitation had a non-significant effect. As for the maximum and mean air temperature, the correlation coefficients were $0.36(\mathrm{p}<0.05)$ and $0.40(\mathrm{p}<0.05)$ for February, and $0.40(\mathrm{p}<0.05)$ and $0.42(\mathrm{p}<0.05)$ for March, respectively. However, on the radial growth, while the maximum temperature in August had a negative effect $(\mathrm{r}=-0.26 ; \mathrm{p}<0.05)$, minimum temperatures in February, March and July had a positive effect $(\mathrm{r}=0.39,0.40$ and 0.34 respectively; $\mathrm{p}<0.05)$. It means while higher rains in July and higher temperatures in the late winter-early spring have caused the wider growth rings, the narrower growth rings have been formed in the years with higher maximum temperatures in August in the isolated coastal site of scots pine.
\end{abstract}

Keywords: Climate, homogeneity index, Scots pine, stand dynamics, tree-ring

PENGARUH IKLIM TERHADAP PERTUMBUHAN RADIAL PINUS SKOTLANDIA Pinus sylvestris L.) PADA TEGAKAN CAMPURAN PANTAI DI KAPISUYU, BARTIN, TURKI. Pinus scot secara geografis merupakan spesies pinus yang paling tersebar luas di dunia, dan menunjukekan respons pertumbuban yang berbeda terhadap pengaruh iklim dan lingkungan di lokasi ekologi yang beragam. Penelitian dilakukan untuk mempelajari dinamika tegakan dan bubungan pertumbuhan iklim pinus scot di tegakan pantai yang terisolasi (baru-baru ini ditemukan) di Wilayah Laut Hitam Barat Turki. Indeks homogenitas tegakan ini bervariasi antara 1,92-3,56. Analisis cincin pertumbuhan menggunakan perangkat lunak. COFECHA dan ARSTAN digunakan masing-masing untuk. kontrol kualitas kronologi dan standardisasi (penurunan) setelah cross-dating kronologi individu. Dengan cara ini, kronologi 58 tabun (1959-2016) dari pinus scot dibangun. Selain itu, perangkat lunak DENDROCLIM digunakan untuk menyelidiki bubungan iklim pertumbuban radial pinus scot. Rata-rata sensitivitas berubah dari 0,163 menjadi 0,331, dengan rata-rata 0,183. Korelasi rata-rata antar pohon dan rasio signal-to-noise masing-masing adalah 0,389 dan 7,012. Dalam hal pengarub curah hujan pada pertumbuhan radial pinus scot di lokasi ini, koefisien korelasinya adalah 0,43 $(p<0,05)$ untuk bulan Desember tabun sebelumnya dan 0,41 $(p<0,05)$ untuk. bulan Juli tahun ini. Untuk semua bulan lainnya, curah bujan tidak memberikan pengaruh yang signifikan. Adapun subu udara maksimum dan rata-rata, koefisien korelasi masing-masing adalah 0,36 $(p<0,05)$ dan 0,40 $(p<0,05)$ untuk bulan Februari, dan 0,40 ( $p<0,05)$ dan 0,42 ( $p<0,05)$ untuk bulan Maret. Namun, pada pertumbuhan radial, sedangkan subu maksimum pada bulan Agustus berpengaruh negatif $(r=-0,26$; $p<0,05)$, subu minimum pada bulan Februari, Maret dan Juli berpengarub positif ( $r=0,39$, 0,40 dan 0,34; $p<0,05)$. Hal ini berarti curah hujan yang lebih tinggi di bulan Juli dan subu yang lebih tinggi di akhir musim dingin-awal musim semi telah menyebabkan lingkaran pertumbuban yang lebih luas, lingkaran pertumbuban yang lebih sempit telab terbentuk pada tabun-

*Corresponding author: yamanbar@gmail.com 
tabun dengan subu maksimum yang lebih tinggi pada bulan Agustus di lokasi pantai terpencil pinus scot.

Kata kunci: Iklim, indeks homogenitas, pinus scot, dinamika tegakan, lingkaran

\section{INTRODUCTION}

The most widely distributed of the pines, scots pine (Pinus sylvestris L.) spreads across the whole Eurasian continent, ranging in latitude from $37^{\circ} \mathrm{N}$ to $70^{\circ} 20^{\prime} \mathrm{N}$ (Mátyás et al., 2004). This species reaches from Scotland, southern Spain, northern Greece, and northern Turkey to northern Manchuria and the Sea of Okhotsk (Critchfield \& Little, 1966). In Turkey, scots pine distributes from Ayancik-Sinop $\left(41^{\circ} 48^{\prime} \mathrm{N}\right)$ at the north to Pinarbaş1-Kayseri $\left(38^{\circ} 43^{\prime} \mathrm{N}\right)$ at the south and from Kağıman-Kars $\left(43^{\circ} 05^{\prime} \mathrm{E}\right)$ at the east to Orhaneli-Bursa $\left(28^{\circ} 50^{\prime} \mathrm{E}\right)$ at the west (Saatçioğlu, 1969; Pamay, 1962). However, recently the southernmost distribution of this species in Turkey has been accepted at GürünSivas (3835'00") (Dağdaş et al., 2005).

The global altitudinal distribution of scots pine is from sea level to $1,000 \mathrm{~m}$ in the northern range, while it is in the montane zone between $1.000-2.700 \mathrm{~m}$ a.s.l. in the southern range. This altitudinal distribution consists of small stands and isolated patches (Mirov, 1967; Vidakovic, 1991; Mátyás et al., 2004). In Turkey, while the highest altitudinal point of scots pine is 3125 $\mathrm{m}$ at Allahuekber Mountain (Genç, 2015), its distribution point at sea level is located in Çamburnu-Sürmene, the Eastern Black Sea Region (Mirov, 1967; Shaw, 1914).

Scots pine is an economically important species used in many different industry sectors due to its easiness to process the wood (Mátyás et al., 2004; Euforgen, 2018). Therefore, the studies have concentrated on understanding and improving its growth traits so far (Mason \& Alia, 2000). Due to scots pine's adaptation to diverse ecological habitats, its genetic variety is enormous, and due to existing of various subspecies, varieties, and forms throughout all of Eurasia (Pamay, 1962; Mátyás et al., 2004), there has been recently an increasing interest on Scots pine's isolated population in extreme ecological habitats to conserve its genetic diversity (Mason \& Alia, 2000). Scots pine is one of the frost-resistant pine species (Chang et al. 2021) and tolerant to poor soils and drought, but also it avoids salt-laden winds and the sites under the warming effect of the sea (Pamay, 1962). A recent review based on many investigations related to scots pine has shown that there are positive relationships between precipitation and radial growth; however, summer and autumn temperatures have a negative impact on the radial growth (Matías \& Jump, 2012). Moreover, due to the negative impacts of global warming throughout the Mediterranean region, a decrease in the radial growth of scots pine in this region during the coming decades is predicted by Reich and Oleksyn (2008). The present study was conducted to investigate: (1) stand-dynamics and (2) climate-growth relationship in the mixed-stand isolated in Kapisuyu-Bartin, one of the closest sites of Scots pine's distribution in Turkey to the sea-level and seaside.

\section{MATERIAL AND METHOD}

\section{A. Study Site and Materials}

The sampling stand was located in İlyasgeçidi, Kapısuyu, Bartın, in the Western Black Sea Region of Turkey (41 ${ }^{\circ} 48^{\prime} 44.75^{\prime \prime} \mathrm{N}$, $32^{\circ} 44^{\prime 29.99 " ~ E) ~(F i g u r e ~ 1) . ~ H e r e, ~ t h e ~ a v e r a g e ~}$ slope was $45 \%$, the aspect was northeast, and the average altitude was $140 \mathrm{~m}$ a.s.l. The soil had a loamy texture and granular structure, and it was optimal in nutritious substance. The dominant forest tree species in the stand 


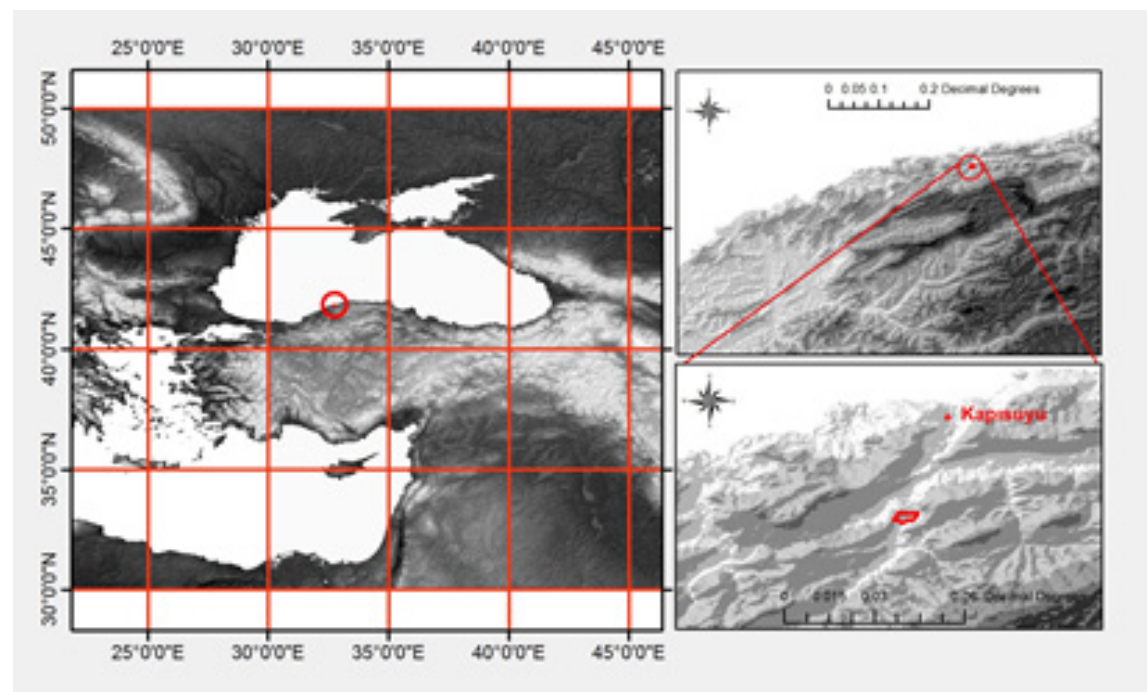

Figure 1. The geographical coordinates of the sampling stand

Table 1. The description of the studied stand

\begin{tabular}{ll}
\hline Stand structure & Traits \\
\hline Number: & 60 \\
Type: & mixed by oriental beech and scots pine \\
Mean canopy closure : & $0.7-0.8$ \\
Mean stand density: & 0.8 \\
Story: & single storied \\
Age: & even-aged \\
Thinning regime: & moderate-high thinning in 2013 \\
Intermediate yield: & $25 \mathrm{~m}^{3}$ for oriental beech, $4 \mathrm{~m}^{3}$ for scots pine in 2013 \\
\hline
\end{tabular}

were Fagus orientalis Lipsky. and Pinus sylvestris L. The stand description is presented in Table 1 (General Forest Directorate, 2017).

\section{B. Methods}

The following formula was used to estimate the number of sample plots in the stand (Kalıpsız, 1994; Batu, 1995).

$$
n \geq \frac{\mathrm{Z}^{2} \times \mathrm{N} \times \mathrm{p} \times(1-\mathrm{p})}{\mathrm{N} \times \mathrm{D}^{2} \times \mathrm{Z}^{2} \times \mathrm{p} \times(1-\mathrm{p})}
$$

where:

n: sample size, Z: confidence level according to the standard normal distribution, $\mathrm{N}$ : population size, p: the estimated proportion of the population that presents the characteristic, $\mathrm{D}$ : tolerated margin of error.
Based on randomized blocks and the result of Equation 1, it was decided to take ten different sample plots that each one was 1000 square meters $(25 \times 40 \mathrm{~m})$. In the sample plots, the number, height and diameter at breast height of trees (DBH), stand canopy closure and stand density were determined, and homogeneity index using the following formula (Equation 2) was calculated (Kapucu et al., 2001; Özçelik 2009; Yücesan et al., 2010; Oktan, 2019).

$$
H I=\frac{\sum_{i=1}^{n-1} \sum_{i=1}^{n-1} \% P_{i}}{\sum_{i=1}^{n-1} \sum_{i=1}^{n-1} \% P_{i}-\sum_{i=1}^{n-1} \sum_{i=1}^{n-1} \% V_{i}}
$$

where:

HI: homogeneity index, \%Pi: cumulative relative frequency values of tree numbers, $\% \mathrm{Vi}$ : cumulative relative frequency values of tree volumes, and n: number of diameter class. 
Also, in the sample plots, the volume was determined for both tree species (P. sylvestris and F. orientalis) based on volume tables constituted by Şenyurt (2011) and Carus (1997), respectively. Using an increment borer, the cores were extracted at the height of $1.3 \mathrm{~m}$ from 12 trees in the stand. The sampled trees were healthy and less than 60 years old. To make the growth rings clear, the transverse surfaces of the cores were sanded using progressively finer grit paper. Samples were cross-dated both "listing the narrow rings" and "skeleton-plot" methods of standard dendrochronological techniques (Yamaguchi, 1991; Stokes \& Smiley, 1996). The ring widths on the transverse surfaces were measured using the VIAS TimeTable (model TT-60-O-100/5) with the precision to the nearest $0.01 \mathrm{~mm}$. The computer program COFECHA was used for testing the crossdating quality of the ring-width measurements (Holmes, 1983; Grissino-Mayer, 2001). Treering series were standardized by fitting a linear or negative exponential regression equation. $\mathrm{Bi}$ weight robust mean values were used to build mean chronology. The program ARSTAN was used for these processes (Cook, 1985; GrissinoMayer et al., 1996), which removes the agesize related trends, and the effects of stand dynamics (Fritts, 1976; Cook et al., 1990a). To explore climate-radial growth relationships, residual chronologies were used, removing autocorrelation and keeping a robust climate signal.

\section{Analysis}

The total annual precipitation and mean temperature (1964-2017) from the Bartin meteorological station, the closest to the sampling stand, was $1046.2 \mathrm{~mm}$ and $12.8^{\circ} \mathrm{C}$, respectively (MGM, 2018). The annual mean for the highest and lowest temperature was $18.9^{\circ} \mathrm{C}$ and $7.6^{\circ} \mathrm{C}$, respectively. The months with the mean highest and lowest temperatures were June $\left(22.1^{\circ} \mathrm{C}\right)$ and January $\left(4.1^{\circ} \mathrm{C}\right)$. The highest and lowest monthly precipitation was in winter and spring, respectively, and there was no water deficiency in the summer (Figure 2). It can be stated that the site studied was under the effects of the oceanic climate.

The monthly mean, maximum, and minimum air temperature and monthly total precipitation values of Bartin Meteorological Station, the closest station having continuous meteorological data to the study site, were taken for the chronology period from 1959 to 2016. To assess climate-radial growth relationships for the duration of the biological year (from October of the previous year to September of the current year), we used Pearson correlation coefficients based on the outputs of DENDROCLIM software (Biondi \& Waikul, 2004).

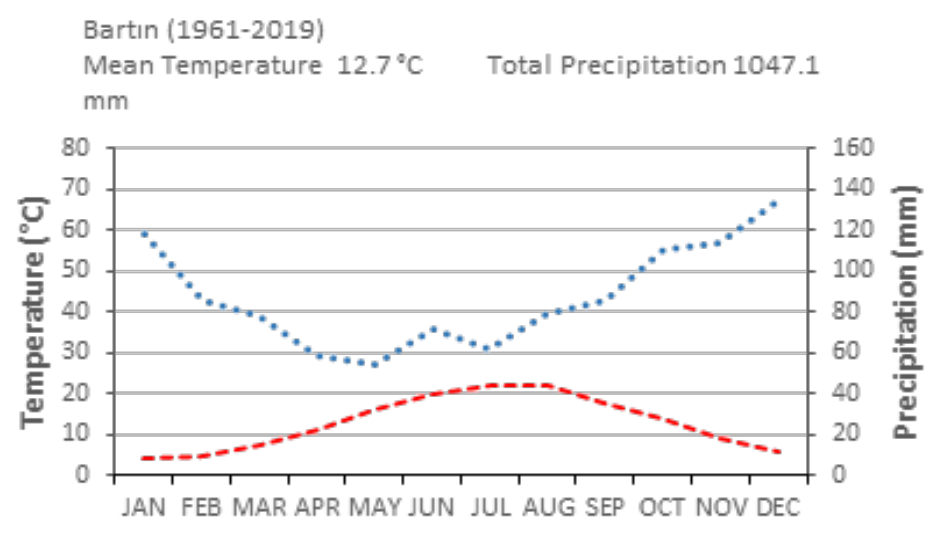

Month

Remarks: - - - Monthly Total Precipitation $(\mathrm{mm}) \quad \ldots .$. Mean Temperature $\left({ }^{\circ} \mathrm{C}\right)$

Figure 2. Ombrothermic diagram of Bartın Region 


\section{RESULTS AND DISCUSSION}

\section{A. Result}

\section{Stand Dynamics}

Descriptive data about stand dynamics of 10 sample plots set in the mixed stand of oriental beech and scots pine in Kapisuyu, in Bartin region are given in Table 2 .

In terms of tree species, there are some differences among sample plots. For oriental beech, the number of trees per ha, mean age, mean height, mean diameter, and the volume per ha vary between 835-1142, 46-123, 15.4 $21.6 \mathrm{~m}, 33.5-54.6 \mathrm{~cm}$ and $773.2-2538.7 \mathrm{~m}^{3}$, respectively. As for scots pine, these parameters vary between $43-823,21-58,8.2-23.7 \mathrm{~m}, 19.2-$ $53.4 \mathrm{~cm}$ and 104.4-1013.2 $\mathrm{m}^{3}$, respectively. Also, the homogeneity index (HI) of sample plots was calculated, and HI varied between 1.92 and 3.56 (Table 3).

\section{Chronology Characteristics}

In this study, a 58-year-long (from 1959 to 2016) chronology of the growth ring widths was constituted for scots pine (Figure 3). Mean sensitivity values changed from 0.163 to 0.331 , with a mean of 0.183 . The chronologies' common interval analysis statistics showed that mean correlation among trees and signal to noise ratio were 0.389 and 7.012 , respectively.
Table 3. Homogeneity Index (HI) of sample plots

\begin{tabular}{cc}
\hline Sample Plot & HI \\
\hline 1 & 3,27 \\
2 & 2,58 \\
3 & 2,47 \\
4 & 1,92 \\
5 & 2,83 \\
6 & 2,96 \\
7 & 3,37 \\
8 & 3,42 \\
9 & 3,35 \\
10 & 3,56 \\
\hline
\end{tabular}

The variance explained by the first eigenvectors of the chronologies was $45.35 \%$ (Table 4).

3. Growth-Climate Relationships Based on Dendroclim Software

Correlation coefficients between the mean chronology and climate variables (monthly mean, maximum and minimum air temperature, and monthly total precipitation) are shown in Figure 4. Concerning the effect of precipitation on the radial growth of scots pine in this site, the correlation coefficients were positive and significant in December of the previous year $(\mathrm{r}=0.43 ; \mathrm{p}<0.05)$ and in July of the current year $(r=0.41 ; p<0.05)$. For all of the other months, precipitation had a weak effect on radial growth ( $p>0.05)$. As for the effect of the

Table 2. Descriptive data about the stand dynamics of the sample plots.

\begin{tabular}{|c|c|c|c|c|c|c|c|c|c|c|c|c|}
\hline \multirow[b]{2}{*}{ 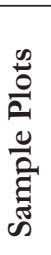 } & \multicolumn{6}{|c|}{ Oriental beech $\nabla$} & \multicolumn{6}{|c|}{ Scots pine $\boldsymbol{\nabla}$} \\
\hline & 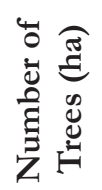 & 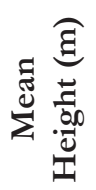 & 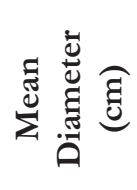 & 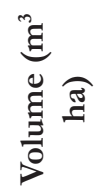 & 莡 & 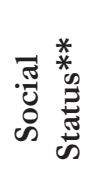 & 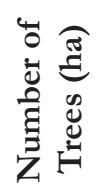 & 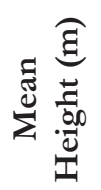 & 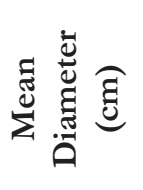 & 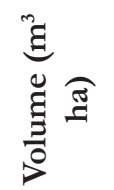 & ${ }_{0}^{*}$ & 吾 \\
\hline 1 & 1050 & 18.2 & 42.5 & 1563.4 & 72 & $\mathrm{D}$ & 43 & 8,2 & 19.2 & 104.4 & 21 & $\mathrm{D}$ \\
\hline 2 & 973 & 17.3 & 38.9 & 1151.1 & 54 & $\mathrm{D}$ & 475 & 19,4 & 41.6 & 710.6 & 39 & $\mathrm{D}$ \\
\hline 3 & 1130 & 15.4 & 33.5 & 1033.9 & 46 & $\mathrm{D}$ & 462 & 21,8 & 51.3 & 1013.2 & 55 & $\mathrm{D}$ \\
\hline 4 & 845 & 16.5 & 35.2 & 773.2 & 49 & $\mathrm{D}$ & 338 & 23,7 & 53.4 & 875.7 & 58 & $\mathrm{D}$ \\
\hline 5 & 1142 & 18.7 & 43.8 & 1700.4 & 76 & $\mathrm{D}$ & 484 & 20,5 & 46.7 & 884.3 & 43 & $\mathrm{D}$ \\
\hline 6 & 1034 & 19.4 & 45.7 & 1884.9 & 85 & $\mathrm{D}$ & 493 & 19,7 & 43.5 & 737.5 & 41 & $\mathrm{D}$ \\
\hline 7 & 870 & 21.3 & 54.6 & 2221.9 & 123 & $\mathrm{D}$ & 678 & 15,3 & 39.3 & 810.9 & 37 & $\mathrm{D}$ \\
\hline 8 & 835 & 20.5 & 52.4 & 2132.5 & 110 & $\mathrm{D}$ & 712 & 12,6 & 33.9 & 656.5 & 30 & $\mathrm{D}$ \\
\hline 9 & 960 & 19.2 & 51.3 & 2096.6 & 106 & $\mathrm{D}$ & 816 & 14,8 & 34.7 & 752.3 & 32 & $\mathrm{D}$ \\
\hline 10 & 994 & 21.6 & 53.5 & 2538.7 & 118 & $\mathrm{D}$ & 823 & 13,7 & 35.8 & 758.8 & 34 & $\mathrm{D}$ \\
\hline
\end{tabular}

Remarks:: *Mean age of sample plot $\quad * *$ D: Dominant

$\boldsymbol{\nabla}$ : Site Index Class: II.Class 


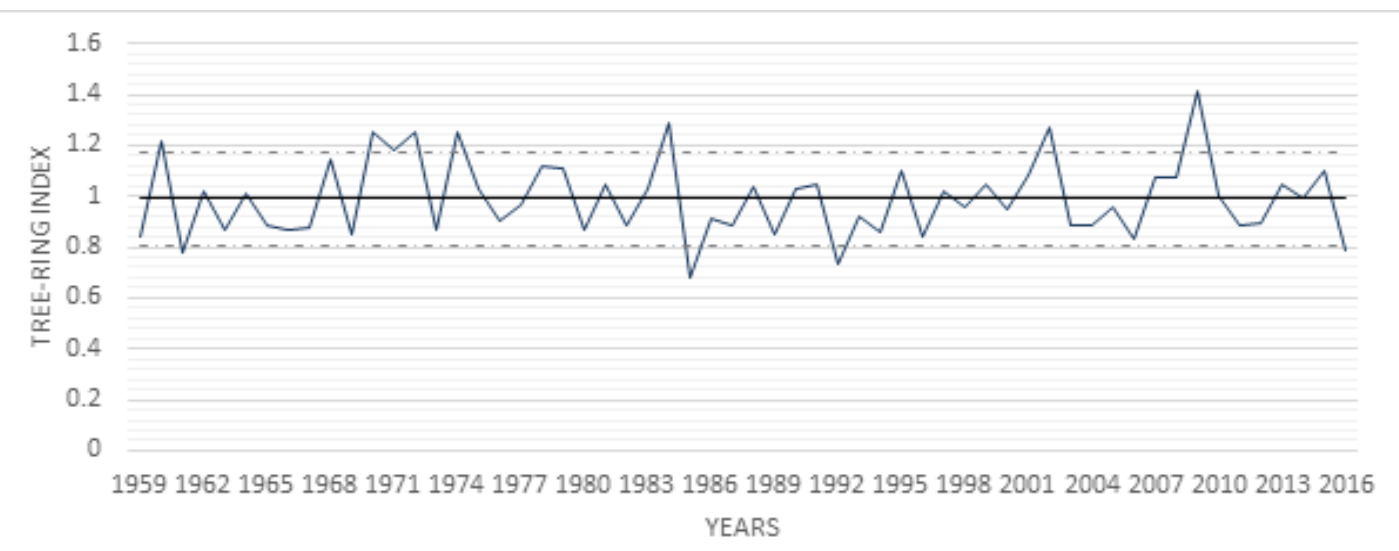

Figure 3. Tree-ring index chronology of scots pine, dotted lines are standard deviations

Table 4. Summary statistics of the chronologies from the ARSTAN program

\begin{tabular}{|c|c|c|}
\hline & Chronology Type & Ring-width \\
\hline \multirow{9}{*}{ 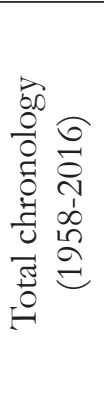 } & Mean & 0.990 \\
\hline & Median & 0.980 \\
\hline & Mean sensitivity & 0.183 \\
\hline & Standard deviation & 0.151 \\
\hline & Skewness & 0.632 \\
\hline & Kurtosis & 0.346 \\
\hline & Autocorrelation order 1 & -0.144 \\
\hline & Partial autocorr. order 2 & 0.087 \\
\hline & Partial autocorr. order 3 & -0.106 \\
\hline \multirow{9}{*}{ 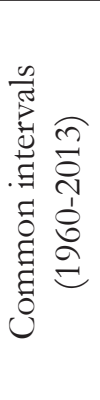 } & Mean correlations: & \\
\hline & Among all radii & 0.389 \\
\hline & Between trees ( $\mathrm{Y}$ variance $)$ & 0.389 \\
\hline & Radii versus mean & 0.660 \\
\hline & Signal-to-noise ratio & 7.012 \\
\hline & Agreement with population chronology & 0.875 \\
\hline & Variance in the first eigenvector $(\%)$ & 45.33 \\
\hline & Chronology common interval mean & 0.995 \\
\hline & Chronology common interval standard deviation & 0.152 \\
\hline
\end{tabular}

mean, maximum and minimum temperature on the radial growth, a strong relationship was found with all of the temperature types. The correlation coefficients for maximum and mean temperature were positive in February $(\mathrm{r}=0.36$ and $\mathrm{r}=0.40$ respectively; $\mathrm{p}<0.05)$ and March ( $r=0.40$ and 0.42 respectively; $\mathrm{p}<0.05)$, but only in August of the current year was the maximum temperature negative $(\mathrm{r}=-0.26$; $\mathrm{p}<0.05)$. As for minimum temperature, it was positive in February, March and July ( $r=0.39$, 0.40 and 0.34 respectively; $\mathrm{p}<0.05$ ).
Scots pine avoids the warming effect of the sea in the southern parts of its global distribution, and its main habitats in Turkey are the inner slopes of the mountains between 700 $-2000 \mathrm{~m}$ a.s.l. The extent to which the climate is oceanic or continental has a big influence on tree growth (Schweingruber, 1988). Based on climate data of Bartin Meteorological Station (OGM, 2018), we can state that the mixed stand of oriental beech and scots pine was under the effects of the oceanic climate, and there isn't a water deficiency in the summer months. Based 


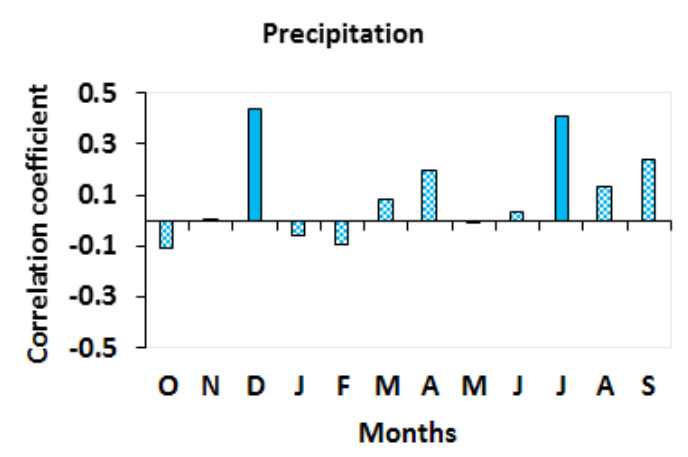

(A)

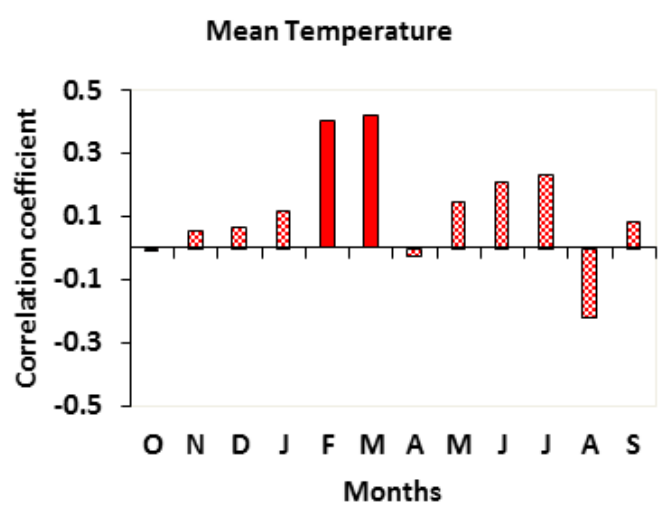

(C)

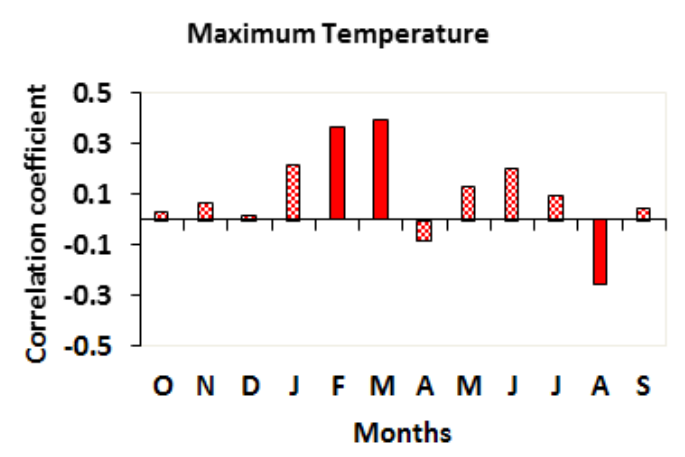

(B)

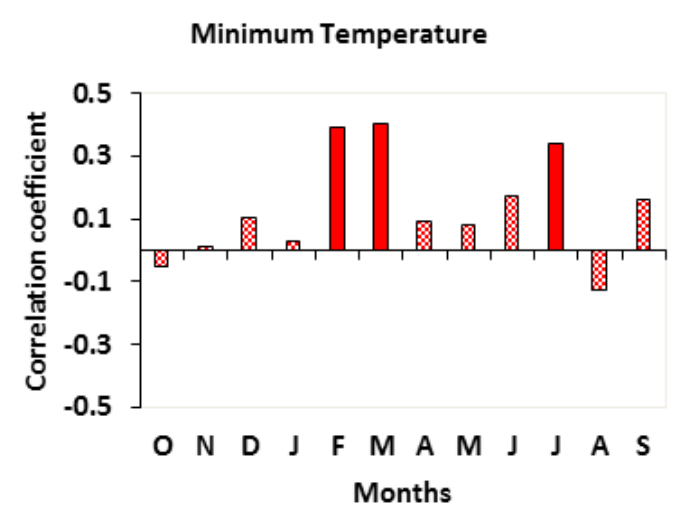

(D)

Figure 4. Correlation coefficients between the radial growth and monthly total precipitation (A), monthly maximum (B), monthly mean (C) and monthly minimum (D) temperature, respectively. Bars of nonpatched colours represent significant coefficients $(p<0.05)$ with the related month

on the dendroclimatological analysis, it appears that, before the beginning of the growth period, December precipitation of the previous growth year and February-March temperatures of the current growth year have a positive impact on the secondary growth of scots pine in this stand. It is known that the cambial activity of trees associated with the growth period begins earlier due to higher temperature values with sufficient precipitation in the pre-growth period of the current year (Schweingruber 1988), and this cause mostly wider tree-ring in the current year (Fritts 1976). Despite the lack of water deficiency in the summer months, it can be stated that narrower tree-rings are formed in the years with higher maximal August temperature in this site. Maximum air temperatures in August has shown an increasing trend in Bartın province (Yaman \& Ertuğrul
2021). The chain reaction mechanisms of trees to climate and environmental factors are very complicated. Because increased respiration at high temperature causes the reduction of net photosynthesis, narrower tree-ring is formed (Fritts, 1976). This might be due to a decrease in Photosystem II abundance at high-temperature stress (Berry \& Bjorkman, 1980; Mathur et al., 2014).

From the perspective of dendroclimatology, scots pine has been studied in different ecological sites throughout its widely native distribution (Bogino et al., 2009; Cedro \& Lamentowicz, 2008; Matisons \& Brumelis, 2008; Panayotov et al., 2013; Savva et al., 2001; Vitas, 2004). Savva et al. (2001) pointed out that local conditions had predominant effect on variation in scots pine's tree-ring parameters along the meridional transects (European, Ural, 
Eastern Siberian, and Far Eastern) in Russia. Vitas (2004) indicated that the radial growth of scots pines in the Baltic Coastal zone of Lithuania had been significantly affected by temperatures in February and September.

Matisons and Brumelis (2008) stated that late winter and early spring temperatures were the main climatic factors influencing the growth of unburied scots pine trees on wooded dunes in Latvia. However, Cedro and Lamentowicz (2008) found that the radial growth of scots pines on a Baltic Bog in Northern Poland was primarily influenced by other reasons than climate, which were water level changes related mainly to anthropogenic activities. Panayatov et al. (2013) determined that droughts occurred in July-August at the lower altitude sites on Vitosha Mountain, Bulgaria, and the low summer temperature at the timberline zone caused the formation of narrow tree rings in scots pine.

Jacoby et al. (1999) found evidence of climate change in Mongolia based on the dendroclimatology of scots pine. Liu et al. (2009) stated that in Hailar, Inner Mongolia, northeastern China, the main affecting climatic factor on the radial growth of Pinus sylvestris is precipitation. However, Bao et al. (2012) found that the mean maximum temperatures from April to September have significant effects on the radial growth of scots pine in the Hulunbuir Region, Inner Mongolia. Bogino et al. (2009) stated that drought is a determining factor in the radial growth of scots pine in Mediterranean conditions in the Iberian Peninsula. In the present study, only August maximum temperature has negatively affected the radial growth of scots pine at the lowest altitudinal site in the Western Black Sea Region of Turkey, which is in the Mediterranean basin.

Moreover, a study by Yaman and Sarıbaş (2004) on the dendroclimatology of scots pine in higher altitudinal stands (approximately $1500 \mathrm{~m}$ above sea-level) in Bartin Province proved that there was a significant positive relation between radial growth and July precipitation index. All these studies and others (Matías \& Jump, 2012) show that scots pine differently responds to climate and site parameters throughout its widely native distribution. This attributes to its high plasticity and adaptive capacity under different ecological conditions. However, due to climate change, scots pine's radial growth is influenced by increased drought stress in its southern limits (Matías \& Jump, 2012).

Until recently, great importance has been given to researches on scots pine's genetic diversity for improving growth traits to increase timber production. However, greater importance is now being paid to the studies related to the conservation of Scots pine's isolated populations under extreme site conditions (Masón \& Alía, 2000). In scots pine's natural distribution in Turkey, its closest stand to the coast is at Camburnu, Trabzon in the Eastern Black Sea Region (Mirov, 1967; Saatçioğlu, 1969; Ata, 1995; Matyas et al., 2004; Shaw, 1914). Except for Çamburnu, the isolated natural stand of scots pine, one of the closest scots pine stand to the coast in Turkey that doesn't exist in silviculture literature, is detected in this research.

Scots pine together with oriental beech constitutes a mixed stand which has even-aged (see explanation in Table 1) and single-storied structure and covered an area of 4.7 ha. In this fully stocked stand having second site quality, the values of Oriental beech varied between 835-1142 for the number of trees, 15.4-21.6 m for tree height, $33.5-54.6 \mathrm{~cm}$ for tree diameter, 46-123 for tree age, and between 773.2-2538.7 $\mathrm{m}^{3}$ for volume per ha. As for scots pine, the values varied between 43-823, 8.2-23.7 m, 19.2-53.4 cm, 21-58, and 104.4-1013.2 $\mathrm{m}^{3}$ respectively. By comparing with the pure and mixed forest structure formed by scots pine in optimal site conditions, these values have been evaluated based on silviculture literature: in terms of the height, diameter, and volume of oriental beech trees, there has not been any difference between its even-aged coast stands (at 150-450 $\mathrm{m}$ a.s.l.) and optimal stands (at 800$1000 \mathrm{~m}$ a.s.l.) in the Western Black Sea Region of Turkey (Carus, 1997). However, in the fully 
stocked scots pine's stands having second site quality in altitudinal ranges above $1000 \mathrm{~m}$ in the same region, Şenyurt (2011) has given the following values: $269-1158$ for the number of trees, 8.9-30.1 $\mathrm{m}$ for tree height, $13.2-46.8 \mathrm{~cm}$ for tree diameter, 18 - 150 for tree age, and 105$1338 \mathrm{~m}^{3}$ for volume per ha. Compared with Şenyurt (2011)'s values, it can be concluded that there exist lower values in the coastal mixed stand of scots pine at $200 \mathrm{~m}$ above sea-level, particularly for the number of trees, tree height, tree age and volume per ha. This result might be due to differences in thinning intensity and exposition to sea effect.

In this study, the homogeneity index was also estimated for each sample plot of the investigated stand. The homogeneity index values have varied between 1.92-3.56 (Table 2). Based on these values, it can be concluded that the mixed stand of oriental beech and scots pine in the coastal region of Bartin shows a homogeneous structure. Although planned as a moderate-high thinning forest based on forest management plan (General Forest Directorate, 2017), both oriental beech and scots pine trees from large diameter class were selected and cut in the silviculture application in 2013. Kapucu (1988) stated that the homogeneity index values have varied between $2.2-4.2$ in evenaged stands applied high thinning. In another study (Özçelik, 2009), the homogeneity index has varied between 1.61-3.54 in the mixed stands of the Western Mediterranean Region of Turkey. According to the homogeneity index, the species in the mixed stands have exhibited the original state of stand structure at the beginning (Oliver \& Larson, 1996; Nyland, 2002). In our study, scots pine is one of the species in the continuous mixing of the stand together with oriental beech, and it is secondary species, which constitutes clustered mixture (40 $\%)$ in the stand.

To investigate scots pine's climate-growth relationship, the present study used monthly climate data. Results show that while higher rains in July and higher temperatures in the late winter-early spring have caused wider growth rings, the narrower growth rings have been formed in the years with higher maximum temperatures in August. Recently, daily climate data has been used in dendroclimatological and dendroecological analyses (Jevšenak, 2020). The future research task in this isolated coastal site is to study scots pine's climate-growth relationship using daily climate data.

\section{CONCLUSION}

In this study, in Bartin province in the Black Sea Region of Turkey, a new natural coastal distribution site of scots pine, an isolated species in this area, was found. Despite being a disturbed stand managed with all of the above treatments, it appears that scots pine responds to both winter-summer temperatures and winter precipitation in this site. Scots pine is a climax species together with oriental beech in this mixed stand having secondary structure. In this homogeneously mixed stand, which is a marginal locality for scots pine throughout its natural distribution in Turkey, the tree mortality rate for both species is close to zero, and it should be protected as a genetic reserve. If not, unlike the forest management plan of Kurucaşile, moderate thinning should be applied in favour of Scots pine, and stand density and canopy closure should not be reduced below 0.8 .

\section{REFERENCES}

Ata, C. (1995). Silvikültür tekniği, Z.K.Ü Bartın Orman Fakültesi, Üniversite Yayın No: 4, Fakülte Yayın No: 3, Bartın.

Bao, G., Liu, Y., \& Linderholm, H.W. (2012). AprilSeptember mean maximum temperature inferred from Hailar pine (Pinus sylvestris var. mongolica) tree rings in the Hulunbuir region, Inner Mongolia, back to 1868 AD. Palaeogeography, Palaeoclimatology, Palaeoecology, 313-314, 162-172.

Batu, F. (1995). Uygulamali istatistik yöntemler, K.T.Ü Orman Fakültesi, Genel Yayın No: 179, Fakülte Yayın No: 22, Trabzon.

Berry, J., \& Bjorkman, O. (1980). Photosynthetic response and adaptation to temperature in 
higher-plants. Annual Review of Plant Physiology, 31, 491-543.

Bogino, S., Nieto, M.J.F., \& Bravo, B. (2009). Climate effect on radial growth of Pinus sylvestris at its southern and western distribution limits. Silva Fennica, 43(4), 609-623.

Carus, S. (1997). Aynı yaşlı doğu kayını (Fagus orientalis Lipsky.) meşcerelerinde hacim artımının meşcere yaşı, bonitet, göğüs yüzeyi ve sosyal gövde sinıflara göre değişimi. İstanbul Üniversitesi Orman Fakültesi Dergisi Seri B, 47(14), 63-79.

Cedro, A., \& Lamentowicz, M. (2008). The last hundred years. dendroecology of scots pine (Pinus sylvestris L.) on a Baltic Bog in Northern Poland: Human impact and hydrological changes. Baltic Forestry, 14(1), 26-33.

Chang, C.Y., Bräutigam, K., Hüner, N.P.A., \& Ensminger, I. (2021). Champions of winter survival: Cold acclimation and molecular regulation of cold hardiness in evergreen conifers. New Phytologist, 229(2), 675-691.

Cook, E. (1985). A time series analysis approach to treering standardization. $\mathrm{PhD}$ Thesis, University of Arizona, Tucson, USA.

Cook, E., Briff, K., Shiyatov, S., \& Mazepa, V. (1990a). Tree-ring standardization and growthtrend estimation. In: Cook E, Kairiukstis LA. (eds) Methods of Dendrochronology: Applications in the Environmental Sciences. Boston, Kluwer Academic Publishers, p. 104-122.

Cook, E., Shiyatov, S., \& Mazepa, V. (1990b). Estimation of the mean chronology. In: Cook E, Kairiukstis LA. (eds) Methods of Dendrochronology: Applications in the Environmental Sciences. Boston, Kluwer Academic Publishers, p. 123-132.

Critchfield, W.B., \& Little, E.L. (1966). Geographical distribution of the Pines of the World. Miscellaneous Publication 991, U.S. Forest Service, Department of Agriculture, Washington D.C.

Dağdaş, S., Turan, İ., \& Kırış, R. (2005). A newly identified relict southernmost Pinus sylvestris L. Stands in Anatolia. Tabiat ve Insan, 39(1), 3-21.

Fritts, H.C. (1976). Tree rings and climate. New York : Academic Press.

General Forest Directorate. (2017). Management plan of Kurucaşile forest range district. General Forest Directorate, Ankara.
Genç, M. (2015). Silvikültürün Temel Esaslar. SDÜ Orman Fakültesi Yayınlar1, No: 44, Isparta.

Grissino-Mayer, H.D. (2001). Research report evaluating crossdating accuracy: A manual and tutorial for the computer program COFECHA. Tree-Ring Research, 57(2), 205221.

Grissino-Mayer, H.D., Holmes, R.L., \& Fritts, H.C. (1996). The International tree-ring data bank program library version 2.0 user's manual. Laboratory of Tree-Ring Research, University of Arizona, Tucson, Arizona.

Holmes, R.L. (1983). Computer-assisted quality control in tree-ring data and measurement. Tree-Ring Bulletin, 43, 69-78.

Jacoby, G.C., D'Arrigo, R.D., Pederson, N., Buckley, B.M., Dugarjav, Ch., \& Mijiddorj, R. (1999). Temperature and precipitation in Mongolia based on dendroclimatic investigations. LAWA Journal, 20(3), 339-350.

Jevšenak, J. (2020). Daily climate data reveal stronger climate-growth relationships for an extended European tree-ring network. Quaternary Science Reviews, 221, 105868.

Kalıpsız, A. (1994). İstatistik Yöntemler. İ.Ü. Orman Fakültesi, Üniversite Yayın No: 3835, Fakülte Yayın No: 427, İstanbul.

Kapucu, F. (1988). Doğu karadeniz bölgesinde doğal karışık meşcereler, kuruluşları ve kavranmasinda kimi parametrelerin uygulanması. İ.Ü. Orman Fakültesi Dergisi Seri:B, 38(1), 102-117.

Kapucu, F., Yavuz, H., \& Gül, A.U. (2001). Dişbudak (Fraxinus angustifolia Wahl.) Meşcerelerinde homojenlik durumunun ve gövde niteliklerinin değerlendirilmesi. Turkish Journal of Agriculture and Forestry, 25, 433-441.

Liu, Y., Bao, G., Song, H., Cai, Q., \& Sun, J. (2009). Precipitation reconstruction from hailar pine (Pinus sylvestris var. mongolica) tree rings in the Hailar Region, Inner Mongolia, China back to 1865 AD. Palaeogeography, Palaeoclimatology, Palaeoecology, 282, 81-87.

Masón, W.L., \& Alía, R. (2000). Current and future status Scots pine (Pinus sylvestris L.) forests in Europe. Invest. Agr. Sist. Recur. For. Fuera de Serie n 1-2000, p. 317-333.

Mathur. S., Divya, A., \& Anjana, J. (2014). Photosynthesis: response to high temperature stress. Journal of Photochemistry and Photobiology B: Biology. 137, 116-126. 
Matías, L., \& Jump, A.S. (2012). Interactions between growth, demography and biotic interactions in determining species range limits in a warming world: the case of Pinus sylvestris. Forest Ecology and Management, 282, 10-22.

Matisons, R., \& Brūmelis, G. (2008). Effect of burial by sand on scots pine (Pinus sylvestris L.) radial growth on seacoast wooded dunes at Cape Kolka, Latvia. Acta Universitatis Latviensis ser. Biology, 745, 131-144.

Mátyás, C., Ackzell, L., \& Samuel, C.J.A. (2004). EUFORGEN Technical guidelines for genetic conservation and use for scots pine (Pinus sylvestris). International Plant Genetic Resources Institute.

Mirov, N.T. (1967). The genus pinus. New York, Ronald Press Company.

MGM (2018). Bartin province's climate data. Retrieve from https://mgm.gov.tr/ veridegerlendirme/il-ve-ilceler-istatistik. aspx?m=BARTIN at 1 January 2020.

Nyland, R.D. (2002). Silviculture (Concepts and applications). New York: The McGraw-Hill Company.

Oktan, E. (2019). Determination of the homogeneity and stand quality values in pure oriental spruce (Picea orientalis (L.) Link.) grown in Turkey. Polish Journal of Environmental Studies, 28(3), 1313-1324.

Oliver, C.D., \& Larson B.C. (1996). Forest Stand dynamics. (Update edition), New York: John Wiley \& Sons.

Özçelik, R. (2009). Batı akdeniz bölgesindeki doğal karışık meşcereler ve kuruluşları. Süleyman Demirel Üniversitesi, Orman Fakültesi Dergisi, Seri A, 1, 8-23.

Pamay, B. (1962). Türkiye'de Sançam (Pinus silvestris L.) Tabii Genclesmesi İmkanlar Üzerine Araştormalar. Tarım Bakanlığı, Orman Genel Müdürlüğü, Sira No:337, Seri No:31, İstanbul.

Panayotov, M.P., Zafirov, N., \& Cherubini, P. (2013). Fingerprints of extreme climate events in Pinus sylvestris tree rings from Bulgaria. Trees, 27, 211-227.

Saatçioğlu, F. (1969). Silvikültürün biyolojik esaslar ve prensipleri. İ.Ü Orman Fakültesi, İ.Ü Yayın No: 1429, O.F Yayın No: 138, İstanbul.
Savva, Y.V., Kuzmina N.A., \& Vaganov, E.A. (2001). Sensitivity of the structural characteristics of tree rings to climatic changes in different climatypes of Scotch pine. Russian Journal of Ecology, 32, 400-407.

Schweingruber, F.H. (1988). Tree rings: Basics and applications of dendrochronology. Dordrecht, D.: Reidel Publishing Company.

Shaw, G.R. (1914). The Genus Pinus. Publications of the Arnold Arboretum No. 5. Riverside Press, Cambridge.

Stokes, M.A., \& Smiley T.L. (1996). An Introduction to tree-ring dating. University of Arizona Press, Tucson.

Şenyurt, M. (2011). Batı Karadeniz yöresi sarıcam mesccerelerinde artum ve büyüme. $\mathrm{PhD}$ Thesis, University of İstanbul, Turkey.

Vitas, A. (2004). Dendroclimatological Research of scots pine (Pinus sylvestris L.) in the Baltic Coastal zone of Lithuania. Baltic Forestry, 10(1), 65-71.

Yamaguchi, D.K. (1991). A simple method for cross-dating increment cores from living trees. Canadian Journal of Forest Research, 21(3), 414-416.

Yaman, B., Sarıbaş, M. (2004). Bartın-kumluca sarıçamlarında (Pinus sylvestris L.) dendroklimatolojik araştırmalar. anadolu Üniversitesi Bilim ve Teknoloji Dergisi - A: Uygulamal Bilimler ve Mühendislik, 5(1), 129135.

Yaman, B. \& Ertuğrul, M. (2021). Change-point detection and trend analysis in monthly, seasonal and annual air temperature and precipitation series in Bartın province in the western Black Sea region of Turkey. Geology, Geophysics and Environment, 46(3), 223-237.

Yücesan, Z., Üçler, A.Ö., \& Oktan, E. (2010). Structure and development in subalpine pure oriental spruce (Picea orientalis (L.) Link) stands in Turkey. Austrian Journal of Forest Science, 3 , 111-130. 